\title{
The Implementation of Government Regulation Number 53 Year 2010 Concerning Discipline of Civil Servants in Bener Meriah Regency 2019 in the Education Personnel Board And Bener Meriah District Training
}

\author{
Susi Sri Yuliarti*1 Muhammad Bin Abubakar ${ }^{2}$ \& Rasyidin ${ }^{2}$ \\ 1Student of the Master Program of Public Administration, Universitas Malikussaleh, Aceh Utara, Indonesia \\ 2Master Program of Public Administration, Universitas Malikussaleh, Aceh Utara, Indonesia \\ *Corresponding Author: susisriyuliarti.st@gmail.com
}

\begin{abstract}
This study examines the implementation of Government Regulation No. 53/2010 concerning Civil Servant Discipline. The research objective is to understand how compliance and barriers to civil servants are in implementing these policies. The theoretical perspective used is the theory of public policy implementation according to Anderson. The research method used is a qualitative research method. The results of the study show that the compliance of civil servants in Bener Meriah Regency in 2019 in implementing Government Regulation Number 53 of 2020 concerning Civil Servant Discipline is still not effectively implemented, both in terms of actors implementing policies, the nature of the administrative process, compliance, and the impact of policies. which is implemented. Internal obstacles are caused by the inadequacy of the BKPP Bener Meriah Regency in supervising and evaluating civil servants who violate disciplinary rules, and the low awareness of civil servants in implementing discipline in duty, which is also influenced by the low reward or appreciation for civil servants who have high discipline and lack of discipline. he stressed that the punishment was given to civil servants who had low discipline by the leadership of the SKPK. External obstacles are caused by the lack of decisiveness and lack of supervision from SKPK leaders in following up on civil servants who violate discipline.
\end{abstract}

Keywords: implementation, discipline, pns

\section{Introduction}

The Bener Meriah Regency Government has implemented Government Regulation Number 53 of 2010 concerning Civil Servant Discipline but it is still not optimal in its application. Civil servant discipline is the ability of civil servants to comply with obligations and avoid prohibitions stipulated in statutory regulations and/or are violated, subject to disciplinary punishment. Civil servants who commit acts of disciplinary offenses will be subject to disciplinary penalties. What is included in the disciplinary violation of civil servants is every word, writing, or act of a civil servant who does not comply with the obligations and/or violates the prohibition against disciplinary provisions, both within and outside of working hours.

Based on the researcher's preliminary observations, it is known that out of 3454 civil servants in Bener Meriah Regency there were disciplinary violations so that civil servants received or were sentenced to light, medium, and severe sentences in 2017-2019. Initial observations show that the percentage of absenteeism of civil servants in carrying out their duties is very high, reaching $80 \%$, which is spread throughout the District Work Units in Bener Meriah Regency, but only a few people are punished with disciplinary punishment with a severe category.

Every year Civil Servants (PNS) commit disciplinary violations and are sentenced to various categories including mild, moderate, and severe. Each year there is an increase in the number of civil servants who commit disciplinary violations in Bener Meriah Regency, which are spread out from 28 District Work Units. However, based on the table recapitulation of disciplinary violations and the percentage of attendance of civil servants in the Bener Meriah Regency Government, it is also known that the number of civil servants who are sentenced to disciplinary punishment is not proportional to the percentage of the absence of civil servants in carrying out their duties or work.

So that raises the assumption that the 28 Regional Work Units and the Bener Meriah District Education 
and Training Personnel Board are not synergized in providing penalties for disciplinary violations to civil servants, and the application of Government Regulation Number 53 of 2010 concerning Civil Servant Discipline in Bener Meriah Regency not optimal when viewed the initial observation data. Based on this phenomenon the researchers took the topic of research on the Implementation of Government Regulation Number 53 of 2010 concerning Discipline of Civil Servants in Bener Meriah Regency.

\section{Formulation of the problem}

1. How is the compliance of civil servants in Bener Meriah Regency with Government Regulation Number 53 of 2010 concerning Civil Servant Discipline?.

2. What are the obstacles to the implementation of Government Regulation Number 53 of 2010 concerning the Discipline of Civil Servants in Bener Meriah Regency in 2019 ?.

\section{Literature Review}

The theory is a very important foundation in understanding, interpreting, and interpreting data, therefore to facilitate interpreting the data in this study, the authors use several theories as follows:

\section{Public Policy Implementation}

Policy implementation is a crucial stage in the public policy process, a policy program must be implemented in order to have the desired impact or purpose. Policy implementation is viewed in a broad sense as the stage of the policy process immediately after the enactment of a law. Implementation is the implementation of laws in which various actors, organizations, procedures, and techniques work together to carry out policies in an effort to achieve policy goals or programs (Budi Winarno, 2014: 147).

According to Anderson (1979: 68), there are 4 aspects that need to be studied in policy implementation, namely:
a. Who implements it;
b. The nature of the administrative process;
c. Obedience; and
d. The impact of implementing a policy or program.

\section{Human Resource Development}

Development (development) is one of the management functions. Development is important because of the demands of work as a result of the era of globalization. Public organizations/government cannot be separated from the influence of the globalization era which requires government officials to provide services according to the wishes of the community. Hasibuan (2002: 69) argues that: "development is an effort to improve technical, theoretical, conceptual, and moral abilities of employees in accordance with the needs of the job/ position through education and training".

The implementation of human resource development basically must be based on the methods that have been determined in the human resource development program. In developing human resources, the objectives, time, process, and method of implementation must be determined. Human resource development is intended as a means of improving performance.

\section{The discipline of the State Civil Apparatus}

State Civil Apparatus (ASN) who are aware of their responsibilities are those who obey their obligations and do not do what is forbidden to do. With the aim of educating and fostering Civil Servants, those who violate their obligations and prohibitions are subject to sanctions, in the form of disciplinary punishment. According to Government Regulation Number 53 of 2010 concerning Civil Servant Discipline in Article 1 paragraph 1, what is meant by the discipline of the state civil apparatus is the ability of the state civil apparatus to comply with obligations and avoid prohibitions stipulated in the Legislation and/or Official Regulations which if not obeyed or being violated is subject to disciplinary punishment. This is an obligation, prohibition, and sanction arrangement if the obligation is not obeyed or the prohibition is violated by ASN.

The disciplinary punishment imposed by the official who has the authority to punish, for the results of a thorough examination of the Civil Servant suspected of violating the prescribed obligations and prohibitions, must be commensurate with the breach of discipline so that it can be accepted by a sense of justice. If the disciplinary penalty is felt by a Civil Servant who has been sentenced to be an unfair act, then he or she can file an objection to the superior official, and in certain cases, it can be submitted to the Civil Service Advisory Board.

The disciplinary punishment given is none other than to improve and educate ASN itself, as well as to carry 
out activities in carrying out official duties properly. Disciplinary penalties can be divided according to the level and type, each according to the nature and severity or lightness of the offense committed, as well as the resulting consequences for the offense committed by the Civil Servant concerned.

\section{Methods}

This study uses qualitative research approached with a descriptive analysis approach, because the problem is very comprehensive, in-depth and very broad. Data collection was carried out by observation, interviews and documentation.

\section{Results and Discussion}

In study conducted by researchers on the implementation of Government Regulation Number 53 of 2010 concerning Civil Servant Discipline, it is known that those implementing policies and implementing actors of Government Regulation Number 53 of 2010 are bureaucratic groups. are all civil servants in Bener Meriah Regency specifically and the Education and Training Personnel Board as government agencies that have the task, main, and function of evaluating the performance of civil servants, including imposing disciplinary violations on civil servants.

The next implementation indicator according to Anderson is the essence of the administrative process. Based on the research results, it is known that the essence of the administrative process in implementing Government Regulation Number 53 of 2010 in Bener Meriah Regency is still ineffective due to the lack of maximum synergy between BKPP Bener Meriah Regency and SKPK which have not reported civil servants thoroughly in violating work discipline, as well as human resource management. who has not been maximal in implementing disciplinary policies in Bener Meriah Regency?

The purpose of disciplinary punishment is to correct and educate civil servants who commit disciplinary offenses. Therefore, every official who has the authority to punish before imposing a disciplinary sentence must first examine a civil servant who has committed a disciplinary offense. An examination is held for civil servants who are suspected of committing disciplinary violations. The purpose of the examination is to find out whether the civil servants concerned have committed disciplinary violations. The examination also aims to find out the background and the things that drive the disciplinary violation. The examination is carried out by the official with the authority to punish or other appointed official by himself.

If an official when examining a State Civil Apparatus who is suspected of committing a disciplinary offense believes that based on the results of his examination, the appropriate disciplinary penalty imposed is beyond his / her authority, then the official is obliged to report this to the office with the authority to punish the higher one. The report is accompanied by examination results and other necessary materials. The official with the higher punishment authority is obliged to pay attention and make a decision on the report.

The third indicator from the aspect of policy implementation that needs to be studied based on Anderson's statement in compliance. Based on the research results, it is known that the compliance of civil servants in implementing Government Regulation Number 53 of 2010 is still very low based on a very high percentage of absenteeism in 2019.

Civil servants who commit disciplinary violations are then given moderate and severe punishments and are transferred to a location or position lower than the previous one as a form of punishment so as not to repeat disciplinary violations, both on duty, carrying out calls, and violating office hours.

Disciplinary violation is any words, writings, or actions of State Civil Servants that violate the provisions of civil servant disciplinary regulations, both inside and outside working hours. A PNS is declared to have violated disciplinary regulations if the said, written, and/or actions are legally proven to violate the provisions regarding obligations. Based on article 1 point 8 of Government Regulation Number 53 of 2010 concerning Civil Servant Discipline, disciplinary punishment is a punishment imposed on Civil Servants for violating the Discipline of Civil Servants which can be sentenced to light, moderate and severe categories.

Compliance in this implementation cannot run effectively if the objects that exercise discipline in work, namely the civil servants in the Bener Meriah Regency Government are not obedient to the application of discipline in work so that it is also ineffective for the Bener Meriah District Education and Training Personnel Agency in implementing regulations or the policy.

According to Anderson, public policy implementation also sees the impact of implementing a policy. In this study, it is known that based on the implementation of Government Regulation Number 53 of 2010 concerning Civil Servant Discipline, it has had a good and positive impact. The positive impact is the creation of a sense of deterrence and will not repeat disciplinary violations again, especially for civil servants who receive moderate and severe sentences.

Government Regulation Number 53 of 2020 in Bener Meriah Regency has experienced obstacles in its 
application. Based on the research results, it was found that there were internal and external obstacles in implementing the policy.

Internal obstacles arise from factors that affect the implementation of policies internally, namely the actors implementing disciplinary policies, in this case, the Bener Meriah District Education and Training Personnel Agency which has the duties, main and functions of supervising and evaluating civil servants, especially in evaluating civil servants who violate the discipline of the rule.

The results of the study state that the provision of rewards and punishments for civil servants in Bener Meriah Regency is still not maximally given by the Education and Training Personnel Board of Bener Meriah Regency so that it affects the low awareness of civil servants in implementing discipline in work and carrying out their duties as public services.

The next internal obstacle is the low awareness of civil servants in implementing discipline in their duties, which is also influenced by the low level of rewards or rewards for civil servants who have high discipline and less strict punishment for civil servants who have low discipline by SKPK leaders in Bener Meriah Regency. , which then affects the synergy between SKPK and BKPP of Bener Meriah Regency which is low and not maximal in implementing the Government Regulation.

Barriers to implementing these government regulations also arise externally. External obstacles that arise are influenced by external factors, namely the SKPK in Bener Meriah Regency as the environment where civil servants work.

The results showed that the head of the agency or SKPK where the PNS worked was still not maximal in implementing Government Regulation Number 53 of 2010 for the PNS. The lack of maximum can be seen from the lack of decisiveness of SKPK leaders in reporting civil servants who violate discipline to the BKPP of Bener Meriah Regency.

The next external obstacle is the weakness of supervision which affects the lack of decisiveness of the SKPK leaders in reporting civil servants to the BKPP Bener Meriah Regency to be punished for disciplinary violations in accordance with the rules stated in Government Regulation Number 53 of 2010. So that it becomes an external obstacle that affects the implementation of disciplinary policies civil servants in Bener Meriah Regency

\section{Conclusions}

Based on the research results above, it can be concluded as follows:

1. Compliance with civil servants of Bener Meriah Regency in 2019 in implementing Government Regulation Number 53 of 2020 concerning Civil Servant Discipline has not been effectively implemented, both from the aspect of actors who implement policies, the nature of the administrative process, compliance, and the impact of implemented policies.

2. Barriers to implementing Government No. 53/2010 concerning Discipline of Civil Servants in Bener Meriah Regency are divided into two types of obstacles, namely internal obstacles, and external obstacles. Internal barriers are caused by the inadequacy of the BKPP Bener Meriah Regency in supervising and evaluating civil servants who violate disciplinary rules, and the low awareness of civil servants in implementing discipline in duty, which is also influenced by the low reward or reward for civil servants who have high discipline and the lack of strict punishment for civil servants who have low discipline by the leadership of the SKPK in Bener Meriah Regency, which is then influenced by the low and not optimal synergy between SKPK and BKPP in Bener Meriah Regency in implementing the Government Regulation. External barriers are caused by the inadequacy seen from the lack of firmness in SKPK leaders in reporting civil servants who violate discipline to BKPP Bener Meriah Regency, and weak supervision affects the lack of decisiveness of SKPK leaders in reporting civil servants to BKPP Bener Meriah Regency to be given penalties for disciplinary violations accordingly. with the rules stated in Government Regulation Number 53 of 2010 concerning Civil Servant Discipline.

\section{Recommendations}

1. It is hoped that BKPP and all SKPKs of Bener Meriah Regency will be more firm in implementing disciplinary rules in accordance with Government Regulation Number 53 of 2010 concerning Civil Servant Discipline so that civil servants are more obedient to applicable disciplinary policies.

2. It is hoped that BKPP and all SKPKs of Bener Meriah Regency will carry out a comprehensive evaluation of the disciplinary violation monitoring system in Bener Meriah Regency. 


\section{References}

Abdul Wahab, Solichin. (2012). Analisis Kebijakan Dari Formulasi Ke Implementasi Kebijakan Negara. Jakarta: Bumi Aksara

Agustino, Leo. (2008). Dasar-Dasar Kebijakan Publik. Bandung: Alfabeta

Ahmad, Himat Rahayu. (2017). Penerapan Metode Outbound Pada Pelatihan Penanaman Sikap Mental Disiplin Dan Jiwa Korsa PNSD Dalam Menumbuhkan Kinerja Pegawai. Universitas Pendidikan Indonesia: Tesis.

Anderson, James E. (1979). Public Policy Making. New York: Holt, Rinehartand Winston.

Aries, Dwi Wahyono. (2015). Implementasi Peraturan Pemerintah Nomor 53 Tahun 2010 Tentang Disiplin Pegawai Negeri Sipil Di Kabupaten Pati. Universitas Negeri Semarang: Tesis.

Budi Winarno. (2014). Kebijakan Publik: Teori, Proses dan Studi Kasus. Yogyakarta: CAPS.

Donalson, Les, dan Edward E Scannel. 1993. Pengembangan Sumber Daya Manusia. Gaya Media Pratama, Jakarta

Ekowati, L, Roro, M. (2009). Perencanaan, implementasi dan evaluasi kebijakan atau program, Pustaka Cakra, Surakarta.

Emilia. H. (2018). Implementasi Peraturan Pemerintah Nomor 53 Tahun 2010 Tentang Disiplin Pegawai Negeri Sipil Pada Badan Pengelolaan Keuangan Dan Aset Daerah Provinsi Kepulauan Riau. Universitas Maritim Raja Ali Haji: Tesis.

Gita, Herni Saputri. (2017). Implementasi Disiplin Aparatur Sipil Negara Dalam Lingkup Satuan Kerja Perangkat Daerah (Studi Di Dinas Pekerjaan Umum Kabupaten Lampung Utara). Universitas Lampung: Tesis.

Grindle, Merilees. (1980). Politic And Policy Implementation In The Third World. New Jersey. Princeston Iniversity Press.

Hasibuan, Malayu S.P. (2002). Manajemen Sumber Daya Manusia, Edisi Revisi, Jakarta PT. Bumi Aksara.

Hessel Nogi S. Tangkilisan. (2002). Kebijakan Publik Yang Membumi, Konsep, Strategi dan Kasus. Yogyakarta: Lukman Offset dan YPAPI.

Irfan, Muhlis. (2002). Efektivitas Diklat Struktural Bagi Pegawai Negeri Sipil (Post Training Evaluation), Puslitbang BKN, Jakarta.

Jamaluddin, M.Said, dkk. (2017). Kedisiplinan Aparatur Sipil Negara Pada Kantor Badan Kependudukan Dan Keluarga Berencana Nasional Provinsi Sulawesi Selatan. Universitas Negeri Makassar: Tesis.

Mangkunegara, Anwar Prabu. (2005). Evaluasi Kinerja SDM. Bandung, Refika Aditama.

Mathis, Robert, John Jackson. (2002). Manajemen Sumber Daya Manusia, Buku 2, PT. Salemba Emban Patria. Jakarta

Moleong, Lexy J. (1999). Metodologi Penelitian Kualitatif, Bandung: PT Remaja Rosdakarya,

Notoadmojo, Soekidjo. (2009). Pengembangan Sumber Daya Manusia. Jakarta, Rineka Cipta.

Peraturan Pemerintah Nomor 101 Tahun 2000 tentang Pendidikan dan Pelatihan PNS

Peraturan Pemerintah Nomor 53 Tahun 2010 Tentang Disiplin Pegawai.

Republik Indonesia, Undang-undang Nomor 5 Tahun 2014 tentang Aparatur Sipil Negara.

Riant, Nugroho. (2008). Kebijakan Publik. Jakarta: Elex Media Komputindo

Rivai, Veithzal, Ella Jauvani Sagala. (2009). Manajemen Sumber Daya Manusia Dari Teori ke Praktik. PT RajaGrafindo Persada.

Sedarmayanti. (2010). Manajemen Sumber Daya Manusia, Reformasi Birokrasi, dan Manajemen Pegawai Negeri Sipil. Bandung: Refika Aditama.

Siagian, Sondang P. (2007). Manajemen Sumber Daya Manusia. Jakarta: PT. Bumi Aksara Simamora.

Subarsono, A.G. (2003). Analisis Kebijakan Publik: Konsep, Teori dan Aplikasi . Yogyakarta: Pustaka Pelajar

Sugiyono. (2001). Metode Penelitian Administrasi, Bandung: Alfabeta,

Thoha, Miftah. 2005. Manajemen Kepegawaian Sipil di Indonesia. Jakarta: Prenada Media.

Wibawa, Samudera.(1992). Studi Implementasi Kebijakan Laporan Penelitian. Yogyakarta: Universitas Gadjah Mada.

Wirawan. (2012). Evaluasi Teori, Model, Standar, Aplikasi dan Profesi. Jakarta: Rajawali Press. 